\title{
Peptide Coupling Challenges on Route to Aza-Pipecolyl Smac Mimetic
}

\author{
Ramesh Chingle and William D. Lubell* \\ Département de Chimie, Université de Montréal, C.P. 6128, Succursale Centre-Ville, \\ Montréal, QC, H3C 3J7, Canada
}

\section{Introduction}

Azopeptides are reactive peptide analogs bearing a diazo dicarbonyl moiety as a dehydro $N$-(acyl)amino acid surrogate [1]. Azopeptides have been employed in the synthesis of peptide analogs bearing semicarbazides as amino amide surrogates, so called azapeptides [2]. For example, the DielsAlder reaction of a diazine residue with cyclopentadiene provided aza-methano-pipecolyl peptide $\mathbf{5}$ (Scheme 1) [1]. In the context of research towards anticancer drugs, we perceive the aza-methanopipecolyl structure as a constrained valine analog for insertion into a mimic of the $N$-terminal AVPI binding motif of the second mitochondria-derived activator of caspases (Smac). Coupling to the azamethano-pipecolyl residue proved however challenging during efforts to prepare Smac mimetic 4.

\section{Results and Discussion}

The AVPI peptide amide $\mathbf{1}$ has served as a lead for the development of Smac mimetics that bind the inhibitor of apoptosis protein-3 and induce apoptosis (Figure 1) [3-6]. Considering the turn conformation adopted by this peptide on receptor binding, constrained analogs such as indolizidinone amino acids have been used to rigidify the Val-Pro dipeptide to enhance potency (e.g., 2) [7-9]. Although such bicyclic amino acid analogs represent an important class of Smac mimetics, their multiple step synthesis has restricted analog development. Employing aza-amino acyl proline analogs as indolizidinone amino acid surrogates, azapeptide smac mimetics (e.g., 3) have been developed that induce cell death by a caspase-9 mediated apoptotic pathway [6]. In the interest to further restrict the conformation of the aza-amino acid residue, aza-methano-pipecolate was pursued as a rigid valine analog in smac mimetic 4.

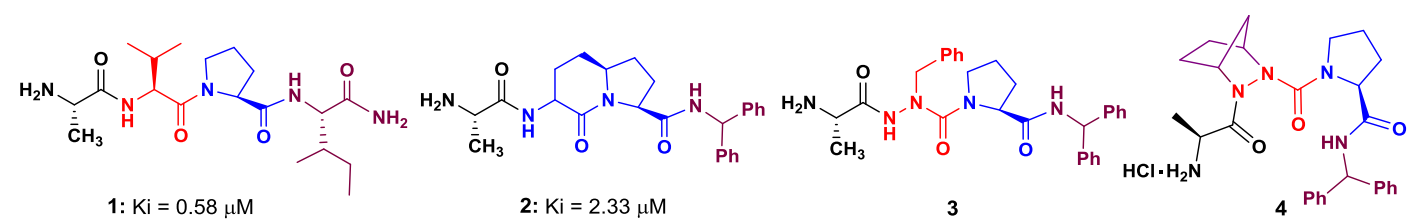

Fig. 1. AVPI-NH2 and peptide mimetic activators of caspase-9.

Hydrogenation aza-Diels-Alder adduct 5 removed the $\mathrm{Cbz}$ group and reduced the olefin to provide bicyclic semicarbazide 6 (Scheme 1). The acylation of semicarbazide 6 with Boc-Ala proved particularly challenging presumably because of the combination of steric hindrance and electronic deactivation. A variety of coupling condition was examined to achieve acylation, albeit with minimal success. For example, various coupling conditions failed to afford the Boc protected aza-tripeptide amide 7: TBTU/HOBT [10], EDCl/HOBT [11], and DIC/AtOH [12]. Moreover, attempts were unsuccessful using the mixed anhydride generated from Boc-Ala, iso-butyl chloroformate and $N$-methylmorpholine $[13,14]$. On the other hand, PyBOP and di-iso-propyl ethyl amine (DIEA) proved effective in the reaction of semicarbazide 6 with Boc-Ala, and gave tripeptide amide 7 in $58 \%$ yield [15]. Removal of the Boc group with $25 \%$ TFA in dichloromethane, salt exchange using $1 \mathrm{~N} \mathrm{HCl}$ for $30 \mathrm{~min}$ and freeze-drying afforded hydrochloride salt 4 (HRMS $\mathrm{m} / z$ calculated for $\mathrm{C}_{27} \mathrm{H}_{34} \mathrm{~N}_{5} \mathrm{O}_{3}$ $[\mathrm{M}+\mathrm{H}]^{+}$476.2656; found 476.2663). 
Scheme 1. Synthesis of aza-methano-pipecolyl Smac mimetic 4.
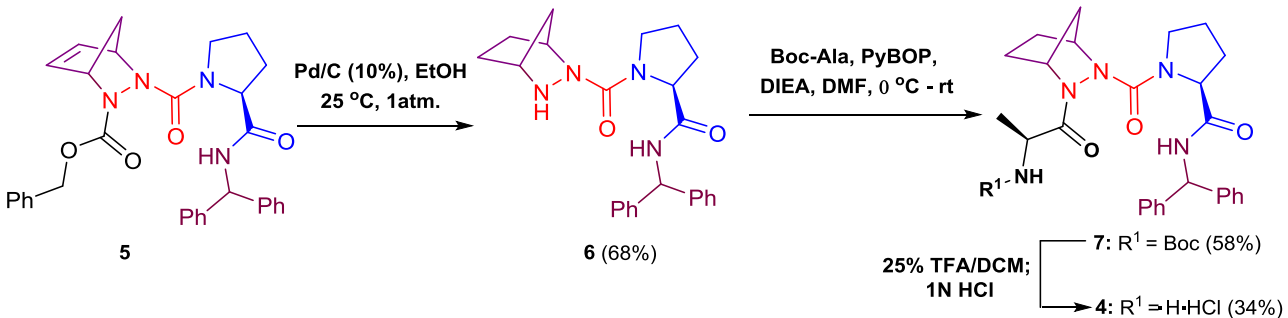

In conclusion, we have disclosed the incorporation of a novel constrained valine into an azapeptide Smac mimetic analog. Application of PyBOP surmounted difficulties in coupling to the bulky and electron deficient aza-methano-pipecolyl residue. Smac mimetic analog $\mathbf{4}$ will be examined for bioactivity to probe further structure-activity relationships at the AVPI binding site towards the development of improved therapy for treating cancer.

\section{Acknowledgments}

This research was supported by the Natural Sciences and Engineering Research Council of Canada (NSERC).

\section{References}

1. Chingle, R., Lubell, W.D. Submitted.

2. Proulx, C., Sabatino, D., Hopewell, R., Spiegel, J., García Ramos, Y., Lubell, W.D. Future Med. Chem. 3, 1139-1164 (2011), http://dx.doi.org/10.1021/jm300557t

3. Kerr, J.F., Wyllie, A.H., Currie, A.R. Br. J. Cancer 26, 239-257 (1972), http://dx.doi.org/10.1038/bjc.1972.33

4. Fadeel, B., Orrenius, S. J. Intern. Med. 258, 479-517 (2005), http://dx.doi.org/10.1111/j.13652796.2005.01570.x

5. Deveraux, Q.L., Reed, J.C. Genes Dev. 13, 239-252 (1999), http://dx.doi.org/10.1101/gad.13.3.239

6. Bourguet, C.B., Boulay, P.-L., Claing, A., Lubell, W.D. Bioorg. Med. Chem. Lett. 24, 3361-3365 (2014), http://dx.doi.org/10.1016/j.bmcl.2014.05.095

7. Sun, H., Nikolovska-Coleska, Z., Yang, C.-Y., Xu, L., Tomita, Y., Krajewski, K., Roller, P.P., Wang, S. J. Med. Chem. 47, 4147-4150 (2004), http://dx.doi.org/10.1021/jm0499108

8. Sun, H., Nikolovska-Coleska, Z., Yang, C.-Y., Xu, L., Liu, M., Tomita, Y., Pan, H., Yoshioka, Y., Krajewski, K., Roller, P.P. J. Am. Chem. Soc. 126, 16686-16687 (2004), http://dx.doi.org/10.1021/ja047438+

9. Khashper, A., Lubell, W.D. Org. Biomol. Chem. 12, 5052-5070 (2014), http://dx.doi.org/10.1039/C4OB00777H

10. Bourguet, C.B., Sabatino, D., Lubell, W.D. Peptide Science 90, 824-831 (2008), http://dx.doi.org/10.1002/bip.21103

11. Chakraborty, T.K., Ghosh, A., Sankar, A.R., Kunwar, A.C. Tetrahedron Lett. 43, 5551-5554 (2002), http://dx.doi.org/10.1016/S0040-4039(02)01141-3

12. Hemmerlin, C., Cung, M.T., Boussard, G. Tetrahedron Lett. 42, 5009-5012 (2001), http://dx.doi.org/10.1016/S0040-4039(01)00917-0

13. Anderson, G.W., Zimmerman, J.E., Callahan, F.M. J. Am. Chem. Soc. 89, 5012-5017 (1967), http://dx.doi.org/10.1021/ja00995a032

14. Zaitsev, A.B., Adolfsson, H. Org. Lett. 8, 5129-5132 (2006), http://dx.doi.org/10.1021/o1062227q

15. Coste, J., Le-Nguyen, D., Castro, B. Tetrahedron Lett. 31, 205-208 (1990), http://dx.doi.org/10.1016/S00404039(00)94371-5 